\title{
Lembrando Regina Marsiglia Remembering Regina Marsiglia
}

\section{Rita Barradas Barata}

Faculdade de Ciências Médicas da Santa Casa de São Paulo. Departamento de Saúde Coletiva. São Paulo, SP, Brasil. E-mail: rita.barradasbarataœgmail.com

\section{Correspondência}

Faculdade de Ciências Médicas da Santa Casa de São Paulo. Rua Dr. Cesário Motta Jr., 6I. São Paulo, SP, Brasil. Cep o1221-020.
Quando os editores da revista Saúde e Sociedade propuseram a publicação do texto "Determinação social do processo epidêmico", originalmente escrito como apoio para um curso introdutório à epidemiologia social a ser realizado no Congresso de Medicina Tropical em Ribeirão Preto no ano de 1982 e organizado por José da Rocha Carvalheiro (naquele momento professor do Departamento de Medicina Social da Faculdade de Medicina de Ribeirão Preto da Universidade de São Paulo), uma série de sentimentos contraditórios me ocorreu.

Inicialmente, ao reler o texto que foi incluído foi incluído no volume Textos de apoio: epidemiologia 1, editado pela Associação Brasileira de Saúde Coletiva (Abrasco) em 1985, cheguei a duvidar se deveríamos publicá-lo agora em um periódico científico, visto que se trata de texto didático escrito em uma fase muito inicial de minha carreira como epidemiologista e que conserva a linguagem e o tom, um pouco naive, daqueles anos nos quais nosso campo da saúde coletiva estava ainda em constituição.

Por outro lado, reler o texto agora, no momento em que a Regina acabava de nos deixar, me fez também pensar que era interessante registrarmos, de maneira mais perene, uma amostra de nosso trabalho conjunto, de colaboração entre epidemiologia e ciências sociais que marcou os primórdios da produção intelectual no campo e que infelizmente foi se tornando progressivamente mais rara ao longo do tempo (Marsiglia, 2013).

Regina e Selma foram e são, para mim, professoras, colegas e principalmente amigas, pessoas que me ajudaram a direcionar e aprofundar meu interesse pela sociologia, conhecer autores e textos seminais, refletir sobre a realidade de saúde da nossa população e sobre a organização do sistema de saúde que tínhamos e o que queríamos.

O convívio com ambas, desde o curso de graduação em medicina, passando pela residência em medicina social e pelos anos de docência compartilhada, foi fundamental para minha opção pela epidemiologia social (Barata, 2005). 
Este convite da Saúde e Sociedade não me fez apenas refletir sobre essas questões da vida acadêmica, mas provocou muitos sentimentos também mistos de alegria e perda. Eu estava longe, trabalhando na Coordenação de Aperfeiçoamento de Pessoal de Nível Superior (Capes), quando a Regina adoeceu e não fiquei sabendo da sua internação. Recebi um choque tremendo quando minha filha me ligou para comunicar que ela havia morrido. Sinceramente, ainda me pego esperando que ela entre na minha sala para trocarmos ideias sobre a terrível situação política em que nos encontramos atualmente. Pego-me muitas vezes esperando ouvir a risada e a voz tão características nos corredores do Departamento. Para mim, é como se eu não pudesse realmente acreditar que ela já não está. A força e o otimismo da Regina faziam a gente acreditar que nada poderia tirá-la do nosso convívio.

Regina era uma amiga para todas as horas, uma professora dedicada e sempre comprometida com a formação dos seus muitos alunos de graduação, especialização, residência, mestrado e doutorado. Era sempre extremamente generosa ao compartilhar seu conhecimento e jamais adotou, do ponto de vista intelectual, posturas que a pudessem afastar dos seus alunos.

Sua capacidade de analisar com clareza os contextos e acontecimentos sociais e seu compromisso constante com a formação de recursos profissionais para o setor da saúde a fizeram militar frequentemente pela qualificação dos profissionais, atuando na rede de serviços públicos não apenas em São Paulo, mas em várias partes do país.

Enfim, ficamos todos mais pobres com a sua falta e em certa medida mais desamparados sem seu otimismo. Para as gerações como as nossas, que foram jovens nas décadas de 1960 e 1970 e acreditaram ser possível fazer deste mundo um lugar melhor, mais justo, democrático, menos desigual, as derrotas recentes provavelmente tiveram um gosto mais amargo. Nesse contexto, pessoas como a Regina e seu exemplo são ainda mais imprescindíveis. Precisamos acreditar que é possível, precisamos continuar tentando levar adiante nossa utopia e jamais nos rendermos ante a barbárie, a violência, a exclusão e a injustiça. Façamos isto para as novas gerações, mas também para honrar aqueles que já não podem nos acompanhar na luta.

\section{Referências}

BARATA, R. B. Epidemiologia social. Revista Brasileira de Epidemiologia, São Paulo, v. 8, n. 1, p. 7-17, 2005.

MARSIGLIA, R. M. G. Temas emergentes em ciências sociais e saúde pública/coletiva: a produção de conhecimento na sua interface. Saúde e Sociedade, São Paulo, v. 22, n. 1, p. 32-43, 2013. 